\title{
EKONOMI SOSIAL SEBAGAI NILAI TAMBAH PETANI KELAPA DALAM PEMBANGUNAN LOKAL
}

\author{
Khairani Alawiyah Matondang 1)*, Bukit Buchori Siagian ${ }^{2)}$ \\ ${ }^{1)}$ Fakultas Ekonomi, Universitas Negeri Medan \\ Email: alawiyah@unimed.ac.id \\ ${ }^{2)}$ Fakultas Ekonomi dan BIsnis, Universitas Sumatera Utara \\ Email :bukitbuchori@gmail.com
}

\begin{abstract}
Abstrak
Penelitian ini menekankan pentingnya ekonomi sosial sebagai penggerak pembangunan lokal. Ekonomi sosial lebih mementingkan pengentasan kemiskinan yang menlanda di pedesaan yang kaya sumberdaya alam. Penelitian ini membahas nilai sosial, kelembagaan sosial, kewirausahaan sosial, dan modal sosial. Penelitian ini menggunakan metode kualitatif, dimana penelitian ini dilakukan di desa Sei Lendir Kabupaten Asahan. Objek penelitian ini adalah petani kelapa dan keluarganya, pengusaha kopra basah, pengrajin kopra basah. Hasil penelitian ini menunjukkan bahwa di desa Sei Lendir sudah berjalan ekonomi sosial yang digerakkan pengusaha kopra basah dengan membentuk kelembagaan informal. Usaha kopra basah ini menjadi salaah usaha mikro yang berkembang dan membuka lapangan kerja baru bagi penduduk sekitar. Hubungan kerja antara pengusaha, petani dan pengrajin kopra basah menciptakan modal sosial berupa adanya kepercayaan, jaringan dan norma. Namun, sayangnya hubungan tersebut hanya menguntungkan sebelah pihak. Oleh karen itu, dibutuhkan kelembagaan ekonomi sosial yang formal untuk membantu para petani dan keluarganya agar dapat hidup sejahtera.
\end{abstract}

Kata Kunci: ekonomi sosial,pembangunan lokal, nilai tambah, kewirausahaan sosial, kelembagaan sosial, modal sosial 


\section{PENDAHULUAN}

Sektor perkebunan menjadi salah satu subsektor pertanian paling cepat berkembang di dunia selama beberapa tahun ini. Naiknya sektor perkebunan ke siginifikansi global telah merangsang pertumbuhan ekonomi dan mengurangi kemiskinan di negara-negara berkembang. Perkebunan kelapa memberikan manfaat langsung yang dapat diperoleh rumah tangga petani miskin sumber daya dengan memproduksi hasil perkebunan untuk konsumsi rumah dengan menggunakan teknologi input sederhana. Petani kelapa di Desa Sei Lendir masih menggantungkan penjualan hasil panen kepada industri pengolahan kopra basah yang membutuhkan daging kelapa. Hanya sebagian kecil saja yang memanfaatkan tempurung kelapa untuk diolah menjadi arang.

Namun, hasil yang dijual tersebut belum mampu mensejahterakan kehidupan petani. Keadaan ini merupakan tantangan yang harus dihadapi secara serius untuk membantu petani kelapa dan keluarganya dapat meningkatkan pendapatan dan mengentaskan kemiskinan di pedesaan. Oleh karena itu, dibutuhkan ekonomi sosial yang mencakup organisasi swasta yang diorganisir secara formal dengan keputusan yang otonom dan kebebasan keanggotaan yang menghasilkan layanan non-pasar untuk rumah tangga dan surplusnya, disesuaikan dengan agen ekonomi yang menciptakan, mengendalikan, atau membiayainya (Monzon, 2012). Nilai tambah ekonomi sosial harus mempertimbangkan manfaat sosial dan ekonomi untuk pembangunan lokal dan kohesi sosial. Ekonomi sosial berkontribusi pada pengembangan sosial ekonomi yang membentuk mentalitas baru untuk lingkungan sosial ekonomi lokal.

Salah satu bentuk ekonomi sosial seperti koperasi yang saling menguntungkan dan asuransi korporasi, yayasan dan semua organisasi nirlaba lainnya yang memegang prinsip yang sesuai dengan sektor ekonomi modern (Barna, 2014). Sementara komponen ekonomi sosial adalah kepecayaan dan jaringan. Tiga kategori utama pemangku kepentingan pada pengembangan sosial ekonomi yaitu otoritas, lembaga publik, masyarakat sipil. Pengembangan sosial ekonomi diperlukan kemitraan dengan lembaga negara melalui pengaturan dana jaminan kredit mikro untuk menciptakan kewirausahaan sosial.

Sejumlah penelitian sebelumnya telah berupaya menganalisis indikator-indikator tentang tingkat
NIAGAWAN Vol 8 No 3 November 2019 produksi,konsumsi dan hubungan yang terkait dengan kewirausahaan sosial. Namun, hasil dan studi ini digeneralisasi dan komparabilitas hasil dibatasi oleh penyebaran metodoligi yang bervariasi. Berdasarkan fenomena yang terjadi, maka penelitian ini bertujuan merevitalisasi sosial ekonomi berbasis perkebunan melalui inovasi teknologi tepat guna untuk meningkatkan produktivitas, nilai tambah, kewirausahaan sosial berbasis potensi suberdaya ekonomi lokal yang berkelanjutan.

\section{TINJAUAN PUSTAKA}

\section{Defenisi Ekonomi Sosial}

Barna (2014) memberikan definisi ekonomi sosial adalah badan usaha nirlaba yang saling menguntungkan dengan memegang prinsip yang sesuai dengan ekonomi modern. Sementara itu, Monzon (2012) menjabarkan ekonomi sosial mencakup organisasi swasta yang diorganisir secara formal dengan otonomi keputusan dan kebebasan keanggotaan yang menghasilkan layanan non pasar untuk rumah tangga, dan surplusnya, jika tidak bisa disesuaikan dengan agen ekonomi yang menciptakan, mengendalikan, atau membiayainya.

Organisasi ekonomi sosial adalah pemain ekonomi dan sosial aktif yang dicirikan terutama oleh tujuan dan tipe kewirausahaan yang spesifik. Organisasi sosial ekonomi sangat aktif di bidang-bidang seperti perlindungan sosial, layanan sosial, kesehatan, dan perbankan, asuransi, pendidikan dan pelatihan, budaya, dan olahraga ( Matei dan Dorobantu, 2015).

Organisasi ekonomi sosial diciptakan untuk memenuhi kebutuhan anggota melalui pasar dengan memproduksi barang dan menyediakan layanan, asuransi dan keuangan, tempat pemgambilan keputusan dan distribusi keuntungan bagi anggota, tidak berhubungan langsung dengan modal atau biaya yang disumbangkan oleh masing-masing anggota.

\section{Peran Transformasi Kelembagaan Tradisional}

Kelembagaan diumpamakan sebagai organ tubuh manusia yang menggerakkan masyarakat. Perubahan lingkungan eksternal menuntut perubahan operasional kelembagaan, termasuk di tingkat lokal (Elizabeth,2010). Kelembagaan lokal yang bersifat tradisional sebagai kelembagaan yang berkembang dan diterima oleh komunitas lokal yang menganut paham ekonomi terbuka. 
Itu mengembangkan kelembagaan lokal ini diperlukan transformasi dan bersinergi agar sesuai dengan perkembangan yang dibutuhkan komunitas. Hayami dan Ruttan mengembangkan Induced Innovation Model yang menjelaskan keterkaitan antara empat faktor yaitu sumberdaya, kultural, teknologi dan kelembagaan (Elizabeth, 2008). Namun, semua itu tidak terlepas dari perubahan struktur dan pola perilaku sosial masyarakat pedesaan. Maka itu, diperlukan pemberdayaan kelembagaan tradisonal dalam pengembangan agroindustri di pedesaan dan pembangunan pertanian.

Uphoff (1992) mengklasifikasi kelembagaan lokal ke dalam beberapa kategori seperti terlihat pada gambar di bawah ini

Gambar 1 Klasifikasi Kelembagaan Lokal

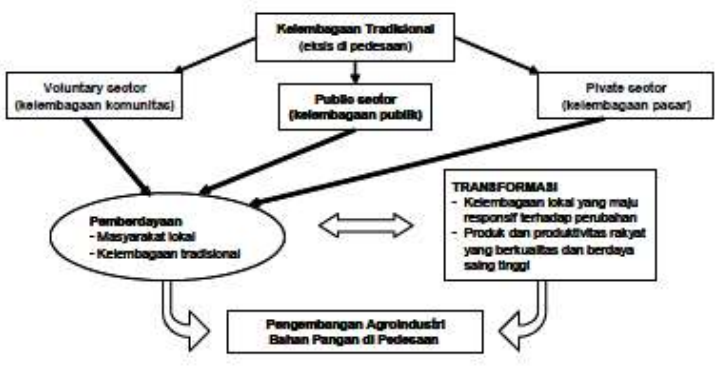

Sumber : Uphoff (1992)

\section{Pemangku Kepentingan Ekonomi Sosial}

Constantinescu (2013) mengatakan bahwa ada tiga kategori pemangku kepentingan yang berkontribusi pada pengembangan sosial ekonomi yaitu otoritas dan lembaga publik; masyarakat sipil dan bisnis. Otoritas dan lembaga publik memiliki peran yang menentukan dalam mempromosikanekonomi sosial. Hal ini dalam dilakukan dengan menjalin kemitraan dengan kelompok sasaran yang ini dikembangkan melalui asosiasi dan representasi (Matei dan Matei, 2012).

Pemangku kepentingan ekonomi sosial yang lain adalah masyarakat sipil melalui koperasi yang terlibat aktif mempromosikan ekonomi sosial. Kegiatan ini mendorong aksi kolektif, pembangunan lokal, dan pembangunan berkelnajutan untuk morang yangmenciptkan produktivitas sosial (Case, 2010). Keuntungan yang diperoleh akan dinvestasikan kembali dalam produksi kualitas umum yang unggul dan efisien (Vlasceanu, 1999).

Pemangku kepentingan ekonomi sosial yang ketiga adalah bisnis yang mempromosikan sosial ekonomi melalui pendirian usaha sosial atau mengembangkan usaha yang sudah mapan. Bisnis juga dapat mendukung pengembangan ekonomi sosial melalui kemitraan dengan
NIAGAWAN Vol 8 No 3 November 2019 lembaga negara melalui pengaturan dana jaminan kredit mikro untuk pendirian dan pengembangan usaha sosial.

Keterlibatan perusahaan dalam kegiatan ini menciptakan kewirausahaan sosial dan menciptakan lingkungan binsis yang etis.

Elemen yang paling nyata dari ekonomi sosial adalah integrasi pada pasar tenaga kerja dari orang-orang yang lemah. Entitas ekonomi sosial adalah pemangku kepentingan dalam proses inovasi sosial melalui barang yang dibuat dan layanan yang diberikan. Ada sebuah hubungan langsung antara pengembangan ekonomi sosial dan pembangunan lokal.

\section{Nilai Tambah Ekonomi Sosial}

Nilai tambah ekonomi sosial tidak terbantahkan lagi. Dalam banyak hal sosial ekonomi secara langsung memberdayakan organisasi itu sendiri. Sementara itu, secara itu tidak langsung menghidupkan kegiatan ekonomi usaha kecil dan penciptaan lapanagan kerja (Constantinescu, 2013). Untuk mendukung keberhasilan kegiatan sosial ekonomi diperlukan pendidikan dan pelatihan untuk meningkatkan produktivitas dan kemampuan pekerja di pasar tenaga kerja.

Tentu saja, hal ini berdampak psitif terhadap penciptaan lapangan kerja sesuai dengan ketrampilan yang dimiliki sehingga rumah tangga petani di pedesaan mampu meningkatkan kesejahteraan menjadi lebih baik.

\section{METODE PENELITIAN}

Penelitian ini menggunakan pendekatan kualitatif, yaitu langsung mengarahkan pada keadaan dan pelaku-pelaku tanpa mengurangi unsur-unsur yang ada di dalamnya. Diharapkan dengan pendekatan ini dapat memahami ekonomi sosial masyarakat petani kelapa.

Sumber data penelitian ini terdiri dari data sekunder dan data primer yang diperoleh dari instansi atau lembaga formal maupun informal. Teknik pengumpulan data bersumber dari lapangan penelitian melalui wawancara, dan pengamatan.Objek penelitian ini adalah keluarga petani kelapa dan pengusaha yang terlibat dalam kegiatan usaha perkelapaan sebanyak lima orang di Desa Sei Lendir Kecamatan Sei Kepayang Barat, Kabupaten Asahan.

\section{HASIL DAN PEMBAHASAN}

Revitalisasi ekonomi sosial untuk meningkatkan produktivitas sangat diperlukan karena petani cenderung kurang beraturan untuk merawat kebun milikinya. Disamping itu, petani masih 
NIAGAWAN Vol 8 No 3 November 2019

menerapkan sistem tradisoinal sehingga pendapatan yang ada tidak mencukupi kebutuhan hidup. Oleh karena itu, pemerintah desa dapat memberikan pelatihan ketrampilan menggunakan sistem pertanian modern yang tepat guna.

Dari hasil wawancara dengan responden diketahui adanya sistem jemput bola yang dilakukan pembeli kepada penjual, dimana pembeli langsung datang ke kebun kelapa dan melakukan transaksi jual beli dengan harga yang disepakati. Namun, keterbatasan pengetahuan pembeli menyebabkan hanya membeli buah kelapa utuh dan daging kelapa segar saja.

Kurang berkembangnya kelembagaan ekonomi menyebabkan petani tidak memiliki posisi tawar yang kuat dengan pengusaha. Berdasarkan hasil wawancara dan pengamatan di lapangan ditemukan bahwa penyaluran hasil panen kelapa hampir seluruhnya dikelola oleh pedagang, mulai dari agen di desa, agen di kecamatan hingga agen di kabupaten. Panjangnya mata rantai tata niaga kelapa membuktikan bahwa petani kelapa menjadi obyek ekonomi abgi lembaga-lembaga perantara dan selalu berada pada psosi yang lemah dan kurang beruntung.

Panajangnya mata rantai tata niaga, mengakibatkan informasi harga di pasar tidak diketahui petani, karena petani tidak mengetahui harga pasar di tingkat konsumen akhir. Oleh karena itu, berdasarkan pernyataan diatas menunjukkan bahw kelembagaan sosial ekonomi yang berkembang di desa ini hanyalah kelembagaan informal. Agar sosial ekonomi berkembang perlu dibentuk kelompok usaha tani yang akan mengorganisir semua kegiatan usaha tani anggota kelompok.

Selama ini,usaha mikro pengelolaan kopra basah telah berkembang dan menyerap tenaga kerja dari semua lapisan umur. Usaha ini mengakibatkan petani kelapa lebih memilih untuk menjual hasil panennya kepada pengusaha kopra basah. Berkembangnya usaha industri skala kecil berbahan baku kelapa mengakibatkan permintaan komoditas kelapa meningkat. Kegiatan pengolahan produk turunan kelapa dan hasil turunannya membuka kesempatan kerja bagi masyarakat lokal. Kegiatan ekonomi lokal ini melahirkan kewirausahaan sosial lokal. Kewirausahaan sosial lokal ini layak untuk dikembangkan karena menggunakan potensi lokal baik sumber daya alam maupun sumber daya manusia. Namun, sayangnya tidak dibarengi dengan peningkatan produktivitas sumber daya alam maupun sumber daya manusia.

Selain permasalahan diatas, petani masih kurang memiliki inovasi dalam penerapan teknologi untuk meningkatkan produktivitas. Untuk itu kelembagaan usaha tani perlu dibentuk dan memiliki peranan penting sebagai pendamping untuk mengembangkan usahatani kelapa di desa ini. Kelembagaan usaha tani ini dapat menjalin kemitraan dengan lembaga penyuluhan dinas terkait untuk memberikan pendidikan dan pelatihan mengenai pembudidayaan tanaman kelapa serta pengolahan produk sampingan kelapa. Dengan demikian mendorong tumbuh dan berkembangnya daya kreativitas dan inovasi petani kelapa, sehingga petani memiliki sumber pendapatan tambahan selain dari hasil panen kebun kelapa untuk meningkatkan kesejahteraan keluarganya.

Dalam rangka mengembangkan usaha tani kelapa dibutuhkan investasi yang cukup besar. Oleh karena itu, dibutuhkan modal yang cukup besar melalui perbankan untuk membiayai kegiatan ini didukung oleh pemerintah daerah. Dengan adanya kelembagaan sosial ekonomi seperti koperasi, maka petani kelapa dapat mengembangkan usahataninya. Selain itu, petani dapat mempromosikan produknya melalui koperasi sehingga posisi tawar petani kelapa menjadi kuat.

Untuk meningkatkan produktivitas petani, maka dapat menjalin kerjasama dengan perguruan tinggi sebagai lembaga penelitian untuk memberikan pendidikan dan pelatihan kepada petani dalam menerapkan hasil penelitian yang dihasilkan.

Dengan demikian, diharapkan ada manfaat yang berhubungan dengan perubahan sistemik dan kelembagaan melalui investasi sosial ekonomi, dimana ada perubahan besar yang digerakkan pada tingkat kebijakan, sikap, atau struktur kelembagaan melalui investasi usaha tani yang dibiayai oleh perbankan dan dukungan pemerintah daerah. Kelembagaan sosial ekonomi dapat memperoleh keuntungan yang lebih besar terhadap pemerintah daerah dan meningkatkan peluang inovasi. Nilai tambah yang dikaitkan dengan struktur sosial ekonomi dapat ditemukan di komunitas petas, dimana kesuksesan berkaitan erat dengan sikap dan perubahan, serta hubungan antara anggota menjadi sangat kuat. 
Struktur ekonomi sosial telah membuktikan bahwa mereka dapat berkontribusi dalam berinovasi dalam memberikan pelayanan kepada konsumen seperti yang dilakukan para pengusaha kopra basah. Hal ini sebagai salah satu bentuk partisipasi demokratis lokal dan pembiayaan sendiri untuk memecahkan masalah sosial yang ada (Case, 2010).

Pembangunan lokal di Desa Sei Lendir melibatkan unsur-unsur inovasi sosial seperti proses pendekatan partisipatif ekonomi sosial, penciptaan struktur kelembagaan baru yang diwujudkan dalam kemitraan, kemitraan antara masyarakat sesama pembuat kopra basah. Semua kegiatan ekonomi lokal menjadi stimulus pembangunan lokal antara pengusaha kopra, petani kelapa dan pengrajin kopra basah.

Efek utama dari kegiatan kewirausahaan sosial terhadap pembangunan lokal berhubungan dengan peningkatan modal sosial. Hal ini terwujud melalui tumbuhnya kepercayaan pada anggota dan lembaga, membangun hubungan yang lebih kuat antara anggota, menciptakan jaringan dengan komunitas hingga stimulasi inovasi dan penyisipan inovasi ke dalam kelembagaan lokal, lapangan kerja hingga penciptaan struktur pembangunan lokal.

Dengan demikian, peluang dan kesempatan kerja menjadi terbuka untuk semua masyarakat yang berpenghasilan rendah. Tentu saja, ini memberikan nilai tambah sosial ekonomi dengan tingkat inklusi yang lebih tinggi. Pembuktian nilai tambah ini dapat dilihat dari penyerapan tenaga kerja, tingkat pendidikan masyarakat yang lebih baik, tingkat penggunaan bantuan sosial dan tingkat kemiskinan yang menurun.

\section{KESIMPULAN DAN SARAN}

\section{Kesimpulan}

Masyarakat di pedesaan masih memiliki pengetahuan dan kemampuan yang terbatas di bidang usaha tani untuk meningkatkan kesejahteraan hidup. Nilai dan kebiasaan ini merupakan warisan dari praktek leluhur. Kebiasaan leluhur dalam usaha tani membutuhkan waktu yang lama untuk membangun dari pola yang salah. Oleh karena itu, harus ada pemberdayaan masyarakat petani melalui sosial ekonomi untuk mengembangkan pola pikir dan pengambilan keputusan.

Kinerja kelembagaan pedesaan selama ini masih dibentuk nilai-nilai tradisional yang rendah, sehingga menjadi salah satu penyebab rendahnya kinerja perekonominan di pedesaan.
NIAGAWAN Vol 8 No 3 November 2019

Maka itu, diperlukan transformasi kelembagaan pertanian tradisional.

Pengembangan ekonomi sosial melalui kelembagaan dapat menciptakan lapangan kerja baru dan menaikkan posisi tawar petani yang lemah. Selain itu dengan adanya kelembagaan tersebut dapat menjadi wadah usahatani sehingga melahirkan kewirausahaan sosial yang tangguh.

Untuk itu diperlukan penguatan kelembagaan untuk mengembangkan inovasi produk agar menjadi nilai tambah produk tani melalui penggunaan teknologi tepat guna agar memberikan inspirasi semangat kerja untuk maju. Program ekonomi sosial akan berhasil menjadi penggerak kemajuan pembangunan lokal jika kelembagaan sosial berjalan sesuai dengan program pembangunan lokal.

Pembangunan lokal harus difokuskan pada sasaran rumah tangga petani. Pembangunan lokal melibatkan unsur-unsur inovasi sosial seperti proses pendekatan partisipatif ekonomi sosial, penciptaan struktur kelembagaan baru yang diwujudkan dalam kemitraan, kemitraan antara masyarakat sesama komunitas. Semua kegiatan ekonomi lokal menjadi stimulus pembangunan lokal antara pengusaha, petani kelapa dan pengrajin.

Efek utama dari kegiatan kewirausahaan sosial terhadap pembangunan lokal berhubungan dengan peningkatan modal sosial. Hal ini terwujud melalui tumbuhnya kepercayaan pada anggota dan lembaga, membangun hubungan yang lebih kuat antara anggota, menciptakan jaringan dengan komunitas hingga stimulasi inovasi dan penyisipan inovasi ke dalam kelembagaan lokal, lapangan kerja hingga penciptaan struktur pembangunan lokal.

\section{Saran}

Dalam pembangunan lokal di pedesaan hendaknya di fokuskan pada pembentukan kelembagaan sosial yang menjadi wadah petani untuk perbaikan dan pembenahan yang berdaya guna. Kelembagaan sosial ini seperti koperasi diharapkan dapat meningkatkan pendapatan, kesempatan kerja dan berusaha di pedesaan.

Selain itu, perlu dilakukannya pendidikan dan pelatihan kepada petani dengan melibatkan perguruan tinggi dan praktisi agar dapat membuka jendela pengetahuan petani 


\section{REFERENSI}

Barna, C. 2014. Atlasul economiei sociale. Bucuresti.

Cace, S. coord. 2010. Economia sociala în Europa. Bucuresti, Editura Expert.

Constantinescu, S. 2013. Economia sociala si ocuparea fortei de munca. Integrarea grupurilor vulnerabile pe piata muncii. Bucuresti, Institutul pentru Economie Sociala (IES).

Elizabeth, R. 2010. Pengembangan Agroindustri Bahan Pangan untuk Peningkatan Nilai Tambah melalui Transformasi Kelembagaan di Pedesaan. Journal Iptek Tanaman Pangan Vol. 5(1).

Elizabeth, R. 2008. Diagnosa kemarjinalan kelembagaan lokal untuk menunjang perekonomian rakyat di pedesaan. Journal on Socio-Economics of Agricultural and Agribussines 8(2):58-64.

Matei, A dan Dorobantu, Daniela.2015. Social Economy-added Value for Local Development and Social Cohesion. Procedia-Economics and Financial.

Matei, L. dan Matei, A. 2012. The social enterprise and the social entrepreneurshipinstruments of local development. A comparative study for Romania. Procedia-Social and Behavioral Sciences.

Monzon, L., Avila, R.C. 2012. The social economy in the European Union. CIRIEC Centre International de recherches et d'information sur l'economie publique, sociale et cooperative.

Uphoff, N. 1992. Local institution and participation for sustainable development. IIED. London.

Vlasceanu M. 1999. Organizatiile si cultura organizarii. Editura Trei, Bucuresti. 